\title{
Safe Cultivation of Medicago sativa in Metal-Polluted Soils from Semi-Arid Regions Assisted by Heat- and Metallo-Resistant PGPR
}

\author{
Anas Raklami ${ }^{1,2,3}{ }^{\mathbb{D}}$, Khalid Oufdou ${ }^{1}$, Abdel-Ilah Tahiri ${ }^{1,2}$, Enrique Mateos-Naranjo ${ }^{4}{ }^{(}$, \\ Salvadora Navarro-Torre ${ }^{3}{ }^{(D}$, Ignacio D. Rodríguez-Llorente ${ }^{3}\left(\mathbb{D}\right.$, Abdelilah Meddich ${ }^{2}{ }^{(D}$, \\ Susana Redondo-Gómez ${ }^{4}$ (i) and Eloísa Pajuelo ${ }^{3, *(1)}$ \\ 1 Laboratory of Biology and Biotechnology of Microorganisms, Faculty of Sciences Semlalia, \\ Cadi Ayyad University, PO Box 2390, Marrakech, Morocco \\ 2 Laboratory of Biotechnology and Plant Physiology, Faculty of Sciences Semlalia, Cadi Ayyad University, \\ PO Box 2390, Marrakech, Morocco \\ 3 Department of Microbiology and Parasitology, University of Seville, PO Box 1095, 41080 Seville, Spain \\ 4 Department of Plant Biology and Ecology, University of Seville, PO Box 1095, 41080 Seville, Spain \\ * Correspondence: epajuelo@us.es; Tel.: +34-954-556-924
}

Received: 17 June 2019; Accepted: 18 July 2019; Published: 22 July 2019

\begin{abstract}
Soil contamination with heavy metals is a constraint for plant establishment and development for which phytoremediation may be a solution, since rhizobacteria may alleviate plant stress under these conditions. A greenhouse experiment was conducted to elucidate the effect of toxic metals on growth, the activities of ROS (reactive oxygen species)-scavenging enzymes, and gene expression of Medicago sativa grown under different metal and/or inoculation treatments. The results showed that, besides reducing biomass, heavy metals negatively affected physiological parameters such as chlorophyll fluorescence and gas exchange, while increasing ROS-scavenging enzyme activities. Inoculation of $M$. sativa with a bacterial consortium of heat- and metallo-resistant bacteria alleviated metal stress, as deduced from the improvement of growth, lower levels of antioxidant enzymes, and increased physiological parameters. The bacteria were able to effectively colonize and form biofilms onto the roots of plants cultivated in the presence of metals, as observed by scanning electron microscopy. Results also evidenced the important role of glutathione reductase $(G R)$, phytochelatin synthase (PCS), and metal transporter NRAMP1 genes as pathways for metal stress management, whereas the gene coding for cytochrome P450 (CP450) seemed to be regulated by the presence of the bacteria. These outcomes showed that the interaction of metal-resistant rhizobacteria/legumes can be used as an instrument to remediate metal-contaminated soils, while cultivation of inoculated legumes on these soils is still safe for animal grazing, since inoculation with bacteria diminished the concentrations of heavy metals accumulated in the aboveground parts of the plants to below toxic levels.
\end{abstract}

Keywords: heavy metal stress; PGPR; rhizobia; legumes; stress related genes; ROS-scavenging enzymes; biofilms; scanning electron microscopy

\section{Introduction}

According to FAO, which declared the past year 2015 as the International Year of the Soils [1], the pressure of the global human population, together with the increasing demand for food, feed, biodiesel, wood, fibers, etc. will force farmers to cultivate plants on poor, degraded, or moderatelypolluted soils [2,3]. Two aspects of the interaction between metals and plants arise when considering cultivation of plants on metal polluted soils: on the one hand, phytoremediation of soils and, on the other hand, a concern for metal accumulation on plant tissues and its subsequent distribution to the 
trophic web [4,5]. In particular, some medicinal plants have been proposed to be grown on polluted soils $[6,7]$, since they behave as metal excluders $[8,9]$, and the low concentrations of metals accumulated in shoots do not affect the ulterior quality of extracted oils or bioactive substances [10-12].

In this context, legumes are also optimum candidates to adapt to degraded soils, particularly to those affected by moderate heavy metal pollution. Legumes are among the plants that have been proposed for phytoremediation [13-16]. These plants behave as metal excluders, since they mainly accumulate metals in the roots and display low translocation to the aboveground part of plants $[13,17]$. In addition, legumes are known for their ability to associate with plant growth-promoting bacteria (PGPR) and rhizobia that generate a biological fertilization of soils that allows the ultimate installation of other plant species and microorganisms [18,19]. These microorganisms can provide nutrients to plants and reduce the adverse effects of contaminants on the plant [20,21]. In this way, plant growth-promoting bacteria (PGPR) and rhizobia-type bacteria associated with leguminous plants used for phytoremediation can contribute to the tolerance, growth, absorption, and acceleration of the process [14,22,23]. Beneficious rhizobacteria improve plant growth by various direct and indirect mechanisms, particularly including PGP activities such as phosphate solubilization, phytohormone production, and deamination of aminocyclopropane carboxylic acid (CCA), the precursor of ethylene, etc. $[24,25]$. Through these mechanisms, the health and the robustness of plants are enhanced, facilitating the adaptation of plants under stressful conditions [26,27]. Furthermore, these bacteria can contribute to the process of phytoremediation, through mechanisms including improved solubilization of metals, siderophore production, production of organic acids and biosurfactants, reduction/oxidation, methylation, precipitation, and biosorption that affect the bioavailability of metals in soils and sediments [22,28,29].

In order to counteract metal stress, plants have evolved multiple extracellular and intracellular mechanisms to tolerate and regulate the uptake of heavy metals. The extracellular mechanisms are manifested by the establishment of symbiotic interactions with bacteria and/or mycorrhizal fungi. $[26,30]$ At the intracellular scale, stress tolerance is associated with the modification of membrane permeability, restriction in water (and metal) uptake, and complexation or immobilization in the rhizosphere, etc. [31,32]. Once inside the cell, heavy metals induce oxidative, osmotic, and ionic stresses in plants [33,34], which are accompanied by the induction of antioxidant enzymes such as superoxide dismutase (SOD), ascorbate peroxidase (APX), glutathione peroxidase (GR), catalase (CAT), and low molecular weight deactivating molecules such as ascorbic acid and thiols such as glutathione and proline. Moreover, the intracellular presence of organic ligands, namely metallothionins, phytochelatins, organic acids, and amino acids, ensures complexation and therefore the detoxification of metal ions [35-37]. From the point of view of omics, adaptation to metals implies the overexpression of multiple genes belonging to different pathways such as cysteine synthase, glutathione transferase, and glutathione reductase for the metabolism of glutathione and phytochelatins, genes of secondary metabolism such as phenylalanine ammonia lyase, and genes involved in drought stress such as the proline synthesis pathway, metal transporters, etc. $[34,38,39]$. Therefore, studies are needed to understand the plant-bacteria relationship and to identify genes and pathways that participate in the management of metal stress.

Accordingly, the present study was conducted with the following objectives: (1) to evaluate the consequence of inoculation with previously selected PGPR on the growth, mineral nutrition, and physiological responses of Medicago sativa to heavy metal stress; (2) to evaluate the effect of PGPR on heavy metal uptake; and (3) to analyze the effect on the activities of ROS-scavenging enzymes and expression level of marker genes belonging to different pathways related to stress management.

\section{Materials and Methods}

\subsection{Plant Growth Conditions and Inoculation Treatments}

M. sativa seeds were surface disinfected with commercial sodium hypochlorite solution diluted $1 / 5(\mathrm{v} / \mathrm{v})$ for $5 \mathrm{~min}$. After several rinsing with distilled water, seeds were placed on wet filter paper 
in petri dishes for germination in the dark at $28{ }^{\circ} \mathrm{C}$ for $24 \mathrm{~h}$. The germinated seeds were sown in plastic pots ( $2 \mathrm{~L}$ capacity) filled with previously sterilized natural compost, sand, and perlite at 1:1:1 ratio $(\mathrm{w} / \mathrm{w})$. The pots were watered with water either supplemented or not with heavy metals at two different concentrations: high metal concentrations (HMC) and low metal concentrations (LMC). HMC corresponded to the following metal concentrations: $\mathrm{Cu}: 2.30 \mathrm{mM}, \mathrm{Pb}: 0.35 \mathrm{mM}$ and $\mathrm{Zn}: 4.30 \mathrm{mM}$. LMC corresponded to the following metal concentrations: $\mathrm{Cu}: 1.15 \mathrm{mM}, \mathrm{Pb}: 0.18 \mathrm{mM}$ and $\mathrm{Zn}: 2.15 \mathrm{mM}$. These concentrations were selected based on the levels of the abovementioned metals found in the Kettara mine, Marrakesh, Morocco [40]. The pots were divided into two different inoculation treatments (inoculated and non-inoculated) with a bacterial consortium composed of four metallo-tolerant strains isolated from metal-polluted soils of the semi-arid region of Marrakech, i.e., Proteus sp. DSP1, Pseudomonas sp. DSP17, Ensifer meliloti RhOL6 and RhOL8. These bacterial strains were isolated from metal polluted soils of the Kettara mine and display, simultaneously, several plant growth-promoting traits (phosphate solubilization, nitrogen fixation, secretion of siderophores, and production of indolacetic acid), besides displaying a high tolerance towards heavy metals $(\mathrm{Cu}, \mathrm{Pb}$, and $\mathrm{Zn}$ ) and high temperatures (Raklami et al., accompanying paper). The rhizobial strains RhLO6 and RhLO8 were grown overnight in yeast extract-mannitol (YEM) medium [41] at $28{ }^{\circ} \mathrm{C}$ with continuous shaking at $140 \mathrm{rpm}$. The PGPR strains DSP1 and DSP17 were cultivated in tryptone soy (TSB) medium at $28^{\circ} \mathrm{C}$ with continuous shaking at $140 \mathrm{rpm}$. The absorbance at $600 \mathrm{~nm}$ of the cultures was adjusted to 1.0 and equal volumes of the four strains were mixed. Every pot was inoculated with $10 \mathrm{~mL}$ of the bacterial consortium at the beginning of the experiment and once a week during the first month. The pots were placed in individual trays in the greenhouse of the Centre for Research, Technology and Innovation of the University of Sevilla, Spain (CITIUS) with a controlled temperature between $21^{\circ} \mathrm{C}$ and $25^{\circ} \mathrm{C}, 40-60 \%$ relative humidity, and natural daylight of $250 \mu \mathrm{mol} \mathrm{m}^{-2} \mathrm{~s}^{-1}$ as a minimum and $1000 \mu \mathrm{mol} \mathrm{m}{ }^{-2} \mathrm{~s}^{-1}$ as a maximum during spring of 2018. Watering was done with $250 \mathrm{~mL}$ of water twice a week.

After two months, plants were harvested. The shoot and root elongation, the number of leaves and the shoot and root fresh weights were measured to evaluate growth. Half of plants harvested were quickly frozen in liquid nitrogen, and stored at $-80{ }^{\circ} \mathrm{C}$ for enzyme assays and gene expression. The rest of plant material was dried at $80^{\circ} \mathrm{C}$ until constant weight for metal and nutrient determination.

\subsection{Chlorophyll Fluorescence and Gas Exchange}

Chlorophyll fluorescence was measured in random primary branches $(n=10)$ using a portable modulated fluorimeter (FMS-2, Hansatech Instrument Ltd., England). Dark and light-adapted fluorescence parameters were measured at midday $\left(1500 \mu \mathrm{mol} \mathrm{m}^{-2} \mathrm{~s}^{-1}\right)$. The minimal fluorescence level in the dark-adapted state (F0) was measured using a modulated pulse $\left(<0.05 \mu \mathrm{mol} \mathrm{m}^{-2} \mathrm{~s}^{-1}\right.$ for $1.8 \mu \mathrm{s})$, and was not sufficient to induce significant physiological changes in the plant. The data stored were an average taken over a 1.6-s period. Maximal fluorescence in this state (Fm) was measured after applying a saturating actinic light pulse of $15,000 \mu \mathrm{mol} \mathrm{m} \mathrm{m}^{-2} \mathrm{~s}^{-1}$ for $0.7 \mathrm{~s}$. The value of Fm was recorded as the highest average of two consecutive points. The same leaf section of each plant was used to measure light-adapted parameters. Steady state fluorescence yield (Fs) was recorded after adapting plants to ambient light conditions for $30 \mathrm{~min}$. A saturating actinic light pulse of $15,000 \mu \mathrm{mol} \mathrm{m} \mathrm{m}^{-2} \mathrm{~s}^{-1}$ for $0.7 \mathrm{~s}$ was then used to produce the maximum fluorescence yield $\left(\mathrm{F}^{\prime} \mathrm{m}\right)$ by temporarily inhibiting photosystem II (PSII) photochemistry. Using fluorescence parameters determined in both light- and dark-adapted states, the following parameters were calculated: maximum quantum efficiency of PSII photochemistry $(\mathrm{Fv} / \mathrm{Fm}=(\mathrm{Fm}-\mathrm{F} 0) / \mathrm{Fm})$ and quantum efficiency of PSII $\left(\Phi P S I I=\left(\mathrm{F}^{\prime} \mathrm{m}-\mathrm{Fs}\right) / \mathrm{F}^{\prime} \mathrm{m}\right)[42]$.

At the same time of chlorophyll fluorescence analysis, gas exchange measurements were taken on random primary branches of each plant $(n=10)$ using an infrared gas analyzer (IRGA) in an open system (LI-6400XT, LI-COR Inc., Neb., USA) equipped with a light leaf chamber (Li-6400-02B, Li-Cor Inc.). Net photosynthetic rate $\left(\mathrm{A}_{\mathrm{N}}\right)$, stomatal conductance $\left(\mathrm{g}_{\mathrm{s}}\right)$, and intercellular $\mathrm{CO}_{2}$ concentration $\left(\mathrm{C}_{\mathrm{i}}\right)$ were all determined at ambient $\mathrm{CO}_{2}$ concentration, temperature of $25-28{ }^{\circ} \mathrm{C}, 50 \pm 5 \%$ relative humidity, 
and a photosynthetic photon flux density (PPFD) of $1000 \mu \mathrm{mol} \mathrm{m} \mathrm{m}^{-2} \mathrm{~s}^{-1}$ to record each measurement. Photosynthetic area was approximated as half the area of the cylindrical branches, as only the upper half received the unilateral illumination in the leaf chamber [43].

\subsection{Determination of Nutrient and Metal Content in Plants}

The determination of nutrient and metal contents in plant tissues (shoots and roots) was performed by ICP-OES from samples of $1 \mathrm{~g}$ dried material at the Ionomics Service of the CEBAS, CSIC (Murcia, Spain).

\subsection{Antioxidant Enzymes Determination}

Enzyme extraction was performed at $4{ }^{\circ} \mathrm{C}$. For that, $0.5 \mathrm{~g}$ fresh root tissues were ground and homogenized in $8 \mathrm{~mL}$ of $50 \mathrm{mM}$ sodium phosphate buffer ( $\mathrm{pH} 7.6$ ) with $0.1 \mathrm{mM}$ Na-EDTA on ice. The homogenate was centrifuged at $9000 \mathrm{rpm}$ for $20 \mathrm{~min}$ at $4{ }^{\circ} \mathrm{C}$. The supernatant was used in enzymatic analyses.

Superoxide dismutase (SOD) was evaluated by monitoring the pyrogallol disappearance spectrophotometrically at $325 \mathrm{~nm}$ for $2 \mathrm{~min}$ [44]. The reaction mixture contained $640 \mu \mathrm{L}$ assay buffer (50 mM potassium phosphate, $\mathrm{pH}$ 7), $360 \mu \mathrm{L}$ of ultra-pure water, and $10 \mu \mathrm{L}$ of plant extract. The reaction was started with the addition of $80 \mu \mathrm{L}$ of pyrogallol $(3 \mathrm{mM})$. For catalase (CAT), the reaction mixture consisted of $890 \mu \mathrm{L}$ of extract buffer ( $50 \mathrm{mM}$ potassium phosphate, $\mathrm{pH}$ 7.6) and $100 \mu \mathrm{L}$ of vegetal extract. The reaction started with the addition of $10 \mu \mathrm{L} 15 \% \mathrm{H}_{2} \mathrm{O}_{2}$. Activity was measured as the decrease in the absorbance at $240 \mathrm{~nm}$ [44]. For ascorbate peroxidase (APX) activity [44], the reaction mixture contained $895 \mu \mathrm{L}$ assay buffer, $100 \mu \mathrm{L}$ of vegetal extract, and $2.72 \mu \mathrm{L}$ of $2 \mathrm{mM}$ $\mathrm{H}_{2} \mathrm{O}_{2}$. The reaction started with the addition of $2.5 \mu \mathrm{L}$ of $0.1 \mathrm{M}$ ascorbate. Activity was recorded as the decrease in absorbance at $290 \mathrm{~nm}$. The reaction of guaiacol peroxidase (GPX) contained $800 \mu \mathrm{L}$ of solution A ( $5.9 \mathrm{~mL}$ of assay buffer, $100 \mu \mathrm{L}$ of vegetal extract, and $2 \mathrm{~mL}$ of $50-\mathrm{mM} \mathrm{H}_{2} \mathrm{O}_{2}$ ). The reaction was initiated with the addition of $200 \mu \mathrm{L}$ of $20 \mathrm{mM}$ guaiacol. The absorbance increase in absorbance was monitored for $2 \mathrm{~min}$ at $470 \mathrm{~nm}$ [44]. All the enzymatic activities were expressed as specific activity in relation to the protein content of the extract, in $\mathrm{mU} \mathrm{mg}^{-1}$ protein, upon application of the formula:

$$
\text { Specific activity }=\frac{\text { micromole of product formed or micromole of substrate consumed }}{\text { min.volume of crude extract }(\mathrm{mL}) \text {.concentration of proteins }\left(\mathrm{mg} \mathrm{mL}^{-1}\right)} \times 1000
$$

\subsection{Global Stress Evaluation: Oxidative Stress Index (OSI)}

Oxidative stress index or OSI is a parameter recently introduced [34,45] to express the extent of the oxidative stress and it is calculated as the average of the prorated values of the different antioxidant enzymes in reference to their values in the control situation, as follows:

$$
\mathrm{OSI}=([\mathrm{SOD}] /[\mathrm{SOD}] 0+[\mathrm{CAT}] /[\mathrm{CAT}] 0+[\mathrm{APX}] /[\mathrm{APX}] 0+[\mathrm{GPX}] /[\mathrm{GPX}] 0) / 4
$$

where [SOD], [CAT], [APX], and [GPX] are the values of these enzymes in the presence of heavy metals (with or without bacteria). [SOD]0, [CAT]0, [APX]0, and [GPX]0 were the control values, i.e., in the absence of both metals and bacteria. A value higher than 1 expressed that the roots were stressed, whereas values lower than 1 corresponded to roots without oxidative stress.

\subsection{Isolation of Plant RNA and qRT-PCR of Stress Related Genes}

Total RNA (two independent extractions for each sample) was extracted from $100 \mathrm{mg}$ root tissue of $M$. sativa grown under different metal /inoculation treatments, using IQeasyTm Plant RNA extraction following the manufacturer instructions. To ensure that there was no residual DNA in RNA preparations, they were additionally treated with DNase (ThermoFisher, USA). Immediately after extraction, all samples were subjected to cDNA synthesis using the QuantiTec Reverse Transcription 
Kit (Qiagen, Hilden, Germany) according to the manufacturer instructions. cDNA samples were stored at $-80{ }^{\circ} \mathrm{C}$ for up one week. The qRT-PCRs were performed using RealMODTM Probe SF2X qPRC mix and an ECO thermocycler (Illumina) following the supplier's instructions. Table 1 shows the primer pairs used for each gene and the Tm used in PCR amplification reactions. The amplification conditions were: initial denaturation at $95^{\circ} \mathrm{C}$ for $2 \mathrm{~min}, 40-50$ cycles at $95^{\circ} \mathrm{C}$ for $5 \mathrm{~s}, 48-66{ }^{\circ} \mathrm{C}$ (depending on the gene) for $10 \mathrm{~s}, 72{ }^{\circ} \mathrm{C}$ for $15 \mathrm{~s}$, and a final step at $95{ }^{\circ} \mathrm{C} 15 \mathrm{~s}, 55^{\circ} \mathrm{C}$ for $15 \mathrm{~s}$, and $95{ }^{\circ} \mathrm{C}$ for $15 \mathrm{~s}$. The housekeeping gene His1 was used to normalize results from different samples. Expression signals were quantified and normalized using EcoTM Software version 4.1.2.0 (Illumina). The expression fold was calculated according to [46]:

$$
\begin{aligned}
& \Delta \mathrm{Cq}=\mathrm{AVECq}(\text { TargetAssay })-\mathrm{AVEC}(\text { ReferenceAssay }) \\
& \Delta \Delta \mathrm{Cq}=\Delta \mathrm{Cq}(\text { TestSample })-\Delta \mathrm{Cq}(\text { ReferenceSample }) \\
& \mathrm{RQ}=2-\Delta \Delta \mathrm{Cq}
\end{aligned}
$$

\subsection{Observation of Biofilms by Scanning Electron Microscopy}

The formation of biofilms onto the plant surface was observed by SEM. For that, plants were cultivated in square plates $(12 \times 12 \mathrm{~cm})$ filled with plant medium consisting of B\&D medium [47] and plant agar $\left(15 \mathrm{~g} \mathrm{~L}^{-1}\right)$. Seeds were disinfected as before and germinated in petri dishes onto wet filter paper for 2 days in the dark. Germinated seed were transferred to square plates containing the agar-B\&D medium without or with metals $(25 \mu \mathrm{M} \mathrm{Cu}, 100 \mu \mathrm{M} \mathrm{Zn}$, and $100 \mu \mathrm{M} \mathrm{Pb})$. Three plates for each condition were inoculated (each seed was inoculated with $100 \mu \mathrm{L}$ of an overnight culture of each strain or the mixture of all of them for the consortium). The plates were sealed, covered outside with black paper until the line of the seeds in order to keep roots from light, and incubated at $25^{\circ} \mathrm{C}$ $/ 15^{\circ} \mathrm{C}$ with $16 \mathrm{~h} / 8 \mathrm{~h}$ dark/light photoperiod for 20 days. After this time, plants were harvested and roots separated and washed three times with sterile distilled water. Pieces of roots of approximately 2-3 mm were fixed with $2.5 \%$ glutaraldehyde dissolved in $0.2 \mathrm{M}$ cacodilate buffer $\mathrm{pH} 7.2$ for $3 \mathrm{~h}$ at room temperature. After washing three times with $0.2 \mathrm{M}$ cacodilate buffer $\mathrm{pH} 7.2$, root samples were dehydrated in acetone series (50\% to 100\%) and dried using the critical point drier Leica EM CPD300 at $31^{\circ} \mathrm{C}$ and $73.8 \mathrm{bar}$, sputtered with $\mathrm{Au}-\mathrm{Pd}(10 \mathrm{~nm})$, and observed with a scanning electron microscope Jeol 6450LV at the Microscopy Service of the University of Sevilla, Spain.

\subsection{Statistical Analysis}

Results are means \pm SE (standard errors) of 10 determinations for growth parameters, three for mineral nutrients and metal accumulation, five for enzymatic activity, and six for gene relative expression (two independent samples $\times$ three replicates). Differences among treatments were assessed by one-way ANOVA; the averages were compared by the Student, Newmann, Keuls (SNK) test. Significant differences at $p<0.05$ are indicated by different letters. 
Table 1. Primers pairs and conditions for qRT-PCR amplification of stress related genes, nodulation genes, and housekeeping genes. The sequences of the primers used for the amplification of the genes His1, GR, NRAMP1, PS, CP450 and PAL were already published [34], while the sequences of the genes ETR, CHS4, LYSM and ENOD2 were reported in [39].

\begin{tabular}{|c|c|c|c|c|c|}
\hline Gene & Name & Tm & Primer Sequence 5'-3' & Expected Band Size & Amplification \\
\hline His1 & Histone 1 & $63^{\circ} \mathrm{C}$ & $\begin{array}{l}\text { FW:5'AGACCACCAAGTACTACTGCAC 3' } \\
\text { RV:5' ATACCAGCCCTCAAACCACCA 3' }\end{array}$ & $150 \mathrm{bp}$ & Positive \\
\hline GR & Glutathione reductase & $63^{\circ} \mathrm{C}$ & $\begin{array}{l}\text { FW:5' GTGCTTCGTGGATGTGTTCCAAAG 3' } \\
\text { RV:5' GTGCTCCAGTCATGCTTCGGATCAG 3' }\end{array}$ & $121 \mathrm{bp}$ & Positive \\
\hline NRAMP1 & $\begin{array}{l}\text { Natural resistance-associated } \\
\text { macrophage proteins transporters }\end{array}$ & $57^{\circ} \mathrm{C}$ & $\begin{array}{l}\text { FW:5' GTTATGCCGCACAATCTTTTC 3' } \\
\text { RV:5’ AGAGCCAATCCTCTTTCTCTATC 3' }\end{array}$ & $119 \mathrm{bp}$ & Positive \\
\hline PS & Phtochelatin synthase & $56^{\circ} \mathrm{C}$ & $\begin{array}{c}\text { FW:5' TTTCAAGTATCCTCCTCACTGGGTTC 3' } \\
\text { RV:5' TTCATCTTTACARCTCACAGTAT 3' }\end{array}$ & $154 \mathrm{pb}$ & Positive \\
\hline CP450 & Cytochrome P450 & $56^{\circ} \mathrm{C}$ & $\begin{array}{l}\text { FW:5'AAAGAAGTGTTGAGGCTGCA 3' } \\
\text { RV:5' ATAGCCCACATGTTGACCAT 3' }\end{array}$ & $128 \mathrm{pb}$ & Positive \\
\hline$P A L$ & Phenylalanine ammonia lyase & $66^{\circ} \mathrm{C}$ & $\begin{array}{c}\text { FW:5' GAAGGTGGACGCCGCCGAGGC 3' } \\
\text { RV:5' GAGCCCACGGAGGTGCCAT 3' }\end{array}$ & $108 \mathrm{pb}$ & Negative \\
\hline ETR & Ethylene receptor & $56^{\circ} \mathrm{C}$ & $\begin{array}{c}\text { FW:5' GVTGTTGCTCTTCTCATGC 3' } \\
\text { RV:5' TGATTCATGACAGCYAGAAAATC 3' }\end{array}$ & $116 \mathrm{pb}$ & Negative \\
\hline CHS4 & Chalcone synthase & $59^{\circ} \mathrm{C}$ & $\begin{array}{l}\text { FW:5' TCAGCTCAAGATGGATTGAAGA 3' } \\
\text { RV: 5' GCCAATTAACACACCCCATT 3' }\end{array}$ & - & Negative \\
\hline LYSM & Receptor of nod factor & $48^{\circ} \mathrm{C}$ & $\begin{array}{c}\text { FW:5' TCTAGTCAACTCCAGCATGGTC 3' } \\
\text { RV:5' CCTTGGAGAAACAACAGTAGTAGACTC 3' }\end{array}$ & - & Negative \\
\hline ENOD2 & Early nodulin 2 & $64{ }^{\circ} \mathrm{C}$ & $\begin{array}{c}\text { FW:5' CGACCACATGTGCATCCACCGGCC 3' } \\
\text { RV:5' CGGGTTTCTCATGAGGTGGTTGG 3' }\end{array}$ & - & Negative \\
\hline
\end{tabular}

Positive: The gene was amplified (confirmed by sequencing). Negative: no amplification was achieved (using DNA as the template) under these conditions or the product identity was not confirmed by sequencing. 


\section{Results}

\subsection{Plant Growth Parameters}

The effect of heavy metals and/or inoculation with bacteria on the growth of M. sativa is illustrated in Figure 1. Results show that cultivation of plants in the presence of heavy metals negatively affected the growth parameters, such as shoot and root lengths and weights, as well as the number of leaves. Moreover, heavy metal stress had significant deleterious effects, causing toxic symptoms in plants shoots like chlorosis and necrosis (not shown). The highest concentration of heavy metals (HMC) was the most stressful and had the strongest consequences on plant biomass of both shoots and roots (36\% and $48 \%$ reduction in case of shoot length and weight, and $22 \%$ and $54 \%$ in the case of roots, respectively). However, inoculation of alfalfa with the bacterial consortium had a significant effect at $p<0.05$. The inoculation clearly promoted plant growth in the absence of metals. The PGPR activity was the most evident in case of $\mathrm{C}+\mathrm{B}$ treatment compared to non-inoculated treatment $(\mathrm{C}-\mathrm{B})$; for instance, the length of shoots increased between $22 \%$ and $77 \%$, whereas shoot fresh weight rose up to $220 \%$ as compared to non-inoculated plants. Moreover, upon metal exposure, the inoculation treatment alleviated the stress; this was evident by the enhancement of growth and the absence of stress symptoms. Only in the highest metal concentration (HMC) were significant diminutions (10-15\%) of shoot and root lengths and weights observed, while the inoculation treatment seemed to fully protect plants under the low metal level (LMC). It should be noted that nodules appeared on the roots of the plants (Figure S1) but, since we inoculated all the four strains in consortium, the nodule occupancy by RhLO6 or RhLO8 or both can not be established.
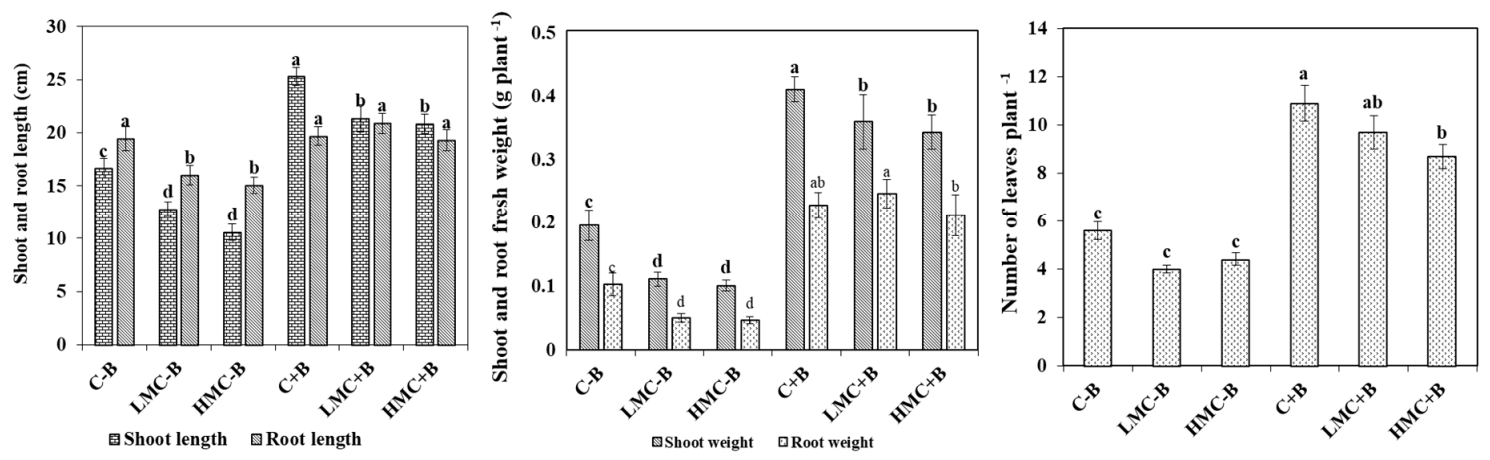

Figure 1. Shoot, root length, and weight and number of leaves of Medicago sativa plants subjected to different treatments. Means $( \pm \mathrm{SE})$ within the same graph followed by different letters are significantly different at $p<0.05$. C-B: control without inoculation; LMC-B: low metal concentrations, without inoculation; HMC-B: high metal concentrations, without inoculation; $\mathrm{C}+\mathrm{B}$ : control inoculated with bacteria consortium; $\mathrm{LMC}+\mathrm{B}$ : low metal concentrations, inoculated with bacteria consortium; HMC+B: high metal concentrations, inoculated with bacteria consortium.

\subsection{Physiological State of The Plants}

Regarding the effect of inoculation on M. sativa photosynthetic rate, our results revealed that maximum quantum efficiency of PSII photochemistry (Fv/Fm) and quantum efficiency of PSII (ФPSII) were greater in plants inoculated with the bacterial consortium. In all cases (Control, LMC, and HMC), inoculation with bacteria led to an increment of $11-57 \%$ and $46-162 \%$ for Fv/Fm and $\Phi$ PSII respectively, with the most apparent effect in plants under metal stress. In addition, the electron transport rate (ETR) was lower in non-inoculated plants than in the inoculated ones; increments between $50 \%$ and $200 \%$ were observed upon inoculation, with significant differences between treatments (one-way ANOVA, $p<0.05$; Figure 2). There was a relationship between net photosynthetic rates $\left(\mathrm{A}_{\mathrm{N}}\right)$ and heavy metal concentration and inoculation. Cultivation of plants under heavy metals stress reduced the $\mathrm{A}_{\mathrm{N}}$ compared to the control. However, the inoculation with the bacterial consortium raised plant photosynthetic rates. In the same way, the stomatal conductance $\left(g_{s}\right)$ was also negatively affected by 
the metal concentration in non-inoculated plants, whereas improvements of 9\% (control), 44\% (LMC), and $122 \%$ (HMC) were observed in plants inoculated with the bacterial consortium compared to non-inoculated plants. The intercellular $\mathrm{CO}_{2}$ concentration $\left(\mathrm{C}_{\mathrm{i}}\right)$ showed the opposite pattern, since $\mathrm{C}_{\mathrm{i}}$ was always higher in non-inoculated plants, probably reflecting lower rates of $C$ fixation. This situation was reverted by inoculation with the metallo-resistant strains which significantly diminished $C_{i}$ values. In general, an overall conclusion is that metals diminished all the physiological parameters in non-inoculated plants, but inoculated plants maintained their physiological state.
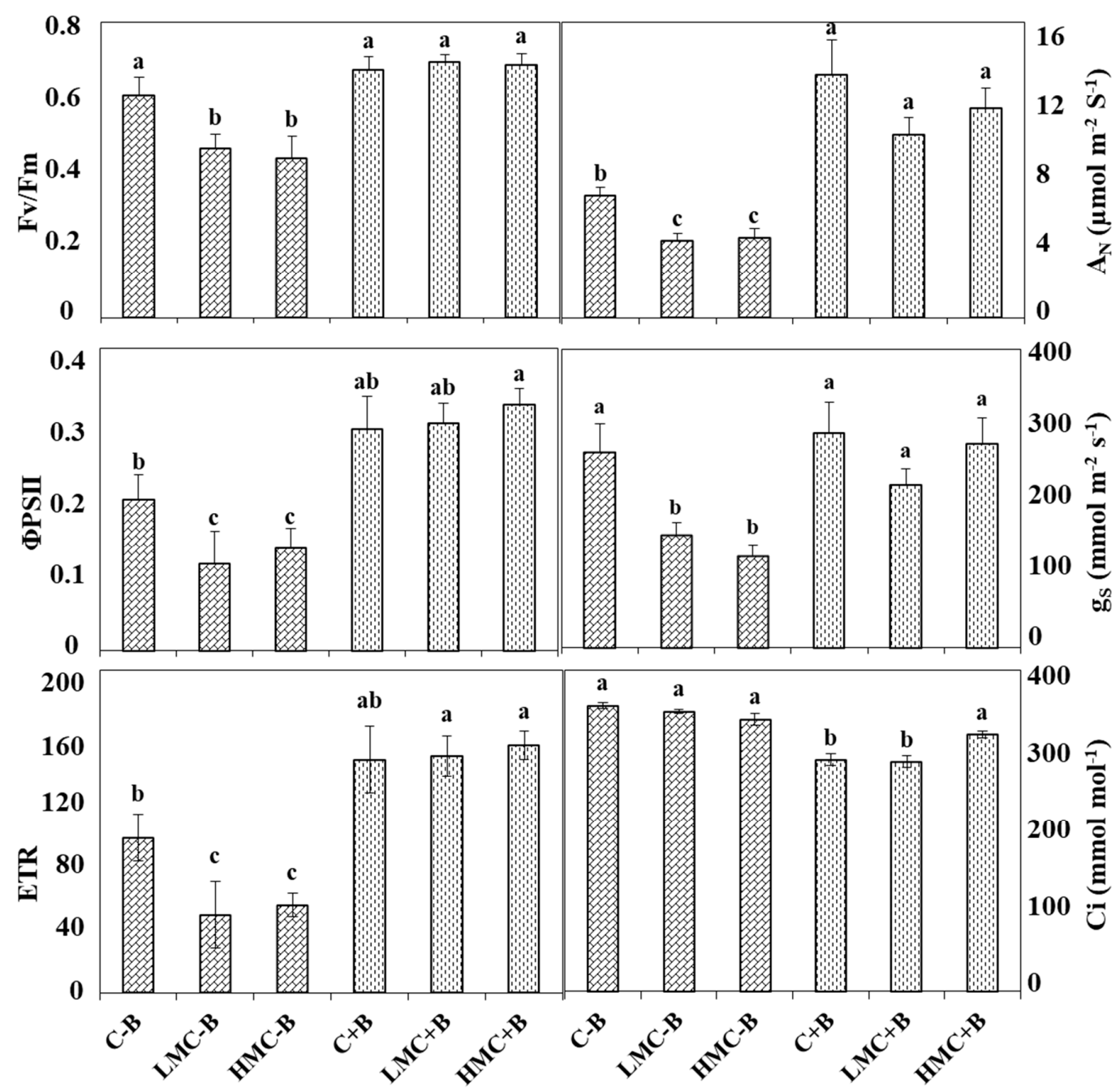

Figure 2. Effect of heavy metals and inoculation treatments (details are in Materials and Methods) on maximum quantum efficiency of PSII (Fv/Fm); quantum efficiency of PSII (ФPSII); electron transport rate (ETR); net photosynthetic rate $\left(\mathrm{A}_{\mathrm{N}}\right)$; stomatal conductance $\left(\mathrm{g}_{\mathrm{s}}\right)$; and intercellular $\mathrm{CO}_{2}$ concentration $\left(C_{i}\right)$, in random primary branches of Medicago sativa plants. Values are means \pm S.E. $(n=10)$. Different letters indicate means that are significantly different from each other $(p<0.05)$. C-B: control without inoculation, LMC-B: low metal concentrations, without inoculation; HMC-B: high metal concentrations, without inoculation; $\mathrm{C}+\mathrm{B}$ : control inoculated with bacteria consortium; $\mathrm{LMC}+\mathrm{B}$ : low metal concentrations, inoculated with bacteria consortium; $\mathrm{HMC}+\mathrm{B}$ : high metal concentrations, inoculated with bacteria consortium.

\subsection{Nutrient Composition of Plants}

The effect of metals and inoculation with metallo-resistant bacteria on nutrient acquisition has been studied. Results are shown in Table 2. Phosphorus metabolism seemed to be affected by inoculation, since the inoculated plants registered significantly higher content of phosphorus than 
the non-inoculated ones, with constant trend. Other element such as sodium showed higher values in inoculated plants. The rest of the elements showed variable differences between inoculated and non-inoculated plants, but without a clear trend.

Table 2. Concentration of mineral nutrients in shoots and roots of alfalfa plants under different heavy metals and/or inoculation treatments. Data are means \pm standard deviations of three independent samples.

\begin{tabular}{cccccccc}
\hline SAMPLE & TISSUE & Ca $(\mathbf{g} / \mathbf{1 0 0 g})$ & $\mathbf{K}(\mathrm{g} / \mathbf{1 0 0 g})$ & $\mathbf{M g}(\mathbf{g} / \mathbf{1 0 0 g})$ & $\mathbf{N a}(\mathbf{g} / \mathbf{1 0 0 g})$ & $\mathbf{P}(\mathrm{g} / \mathbf{1 0 0 g})$ & $\mathbf{S}(\mathrm{g} / \mathbf{1 0 0 g})$ \\
\hline \multirow{2}{*}{ C-B } & SHOOT & $2.03 \pm 0.03$ & $2.58 \pm 0.04$ & $0.29 \pm 0.01$ & $0.07 \pm 0.01$ & $0.20 \pm 0.03$ & $0.63 \pm 0.04$ \\
\cline { 2 - 8 } & ROOT & $0.19 \pm 0.02$ & $1.34 \pm 0.02$ & $0.16 \pm 0.02$ & $0.06 \pm 0.01$ & $0.23 \pm 0.02$ & $0.23 \pm 0.02$ \\
\hline \multirow{2}{*}{ LMC-B } & SHOOT & $1.38 \pm 0.02$ & $2.69 \pm 0.02$ & $0.36 \pm 0.03$ & $0.12 \pm 0.02$ & $0.22 \pm 0.02$ & $0.48 \pm 0.02$ \\
\cline { 2 - 8 } & ROOT & $0.59 \pm 0.01$ & $3.39 \pm 0.05$ & $0.36 \pm 0.01$ & $0.16 \pm 0.02$ & $0.40 \pm 0.03$ & $0.58 \pm 0.05$ \\
\hline \multirow{2}{*}{ HMC-B } & SHOOT & $1.94 \pm 0.02$ & $2.42 \pm 0.01$ & $0.33 \pm 0.02$ & $0.07 \pm 0.01$ & $0.19 \pm 0.01$ & $0.57 \pm 0.03$ \\
\cline { 2 - 8 } & ROOT & $0.37 \pm 0.03$ & $1.73 \pm 0.02$ & $0.34 \pm 0.02$ & $0.15 \pm 0.02$ & $0.27 \pm 0.03$ & $0.44 \pm 0.02$ \\
\hline \multirow{2}{*}{ C+B } & SHOOT & $1.37 \pm 0.02$ & $2.09 \pm 0.01$ & $0.22 \pm 0.02$ & $0.13 \pm 0.02$ & $0.55 \pm 0.03$ & $0.38 \pm 0.01$ \\
\cline { 2 - 8 } & ROOT & $0.30 \pm 0.01$ & $0.95 \pm 0.02$ & $0.22 \pm 0.01$ & $0.39 \pm 0.03$ & $0.49 \pm 0.04$ & $0.22 \pm 0.04$ \\
\hline \multirow{2}{*}{ LMC+B } & SHOOT & $1.33 \pm 0.02$ & $2.59 \pm 0.03$ & $0.34 \pm 0.02$ & $0.51 \pm 0.02$ & $0.33 \pm 0.02$ & $0.41 \pm 0.02$ \\
\cline { 2 - 7 } & ROOT & $0.21 \pm 0.02$ & $1.70 \pm 0.02$ & $0.17 \pm 0.01$ & $0.32 \pm 0.03$ & $0.47 \pm 0.01$ & $0.24 \pm 0.03$ \\
\hline \multirow{2}{*}{ LMC+B } & SHOOT & $2.00 \pm 0.03$ & $4.00 \pm 0.02$ & $0.45 \pm 0.03$ & $0.42 \pm 0.04$ & $0.45 \pm 0.02$ & $0.64 \pm 0.03$ \\
\cline { 2 - 7 } & ROOT & $0.28 \pm 0.02$ & $1.88 \pm 0.01$ & $0.21 \pm 0.02$ & $0.38 \pm 0.01$ & $0.57 \pm 0.03$ & $0.31 \pm 0.04$ \\
\hline
\end{tabular}

\subsection{Determination of Antioxidant Enzymes}

In order to understand antioxidant enzymes involved in management of the oxidative stress caused by heavy metals, the activities of SOD, CAT, APX, and GPX were evaluated (Figure 3). Increasing concentrations of heavy metals significantly induced enzyme activity of $M$. sativa compared to the control in both inoculated and non-inoculated treatment. SOD activity seemed to be the enzyme with the highest involvement in stress management, since the values of this enzyme always increased by $25-93 \%$ while CAT was enhanced by $44-82 \%$, whereas APX activity did not increase for some treatments (LMC). Moreover, the inoculation with the bacterial consortium led to a reduction of the activities of ROS-scavenging enzymes in $M$. sativa roots. Treatment with this consortium reduced GPX activity by $9-13 \%$. The largest reduction of enzymatic activity was noticed in the cases of SOD (40-67\%) and CAT (31-57\%). On its side, APX activity registered decreases of $48 \%$ and $31 \%$ at LMC and HMC as compared to the corresponding non-inoculation treatments. In general, it could be said that inoculation with bacteria kept the levels of ROS-scavenging enzymes below the level of non-exposed plants at the low metal concentration (LMC). Only at the highest concentration of metals (HMC) did the levels of some enzymes increase, although they always remained below those of non-inoculated plants. 

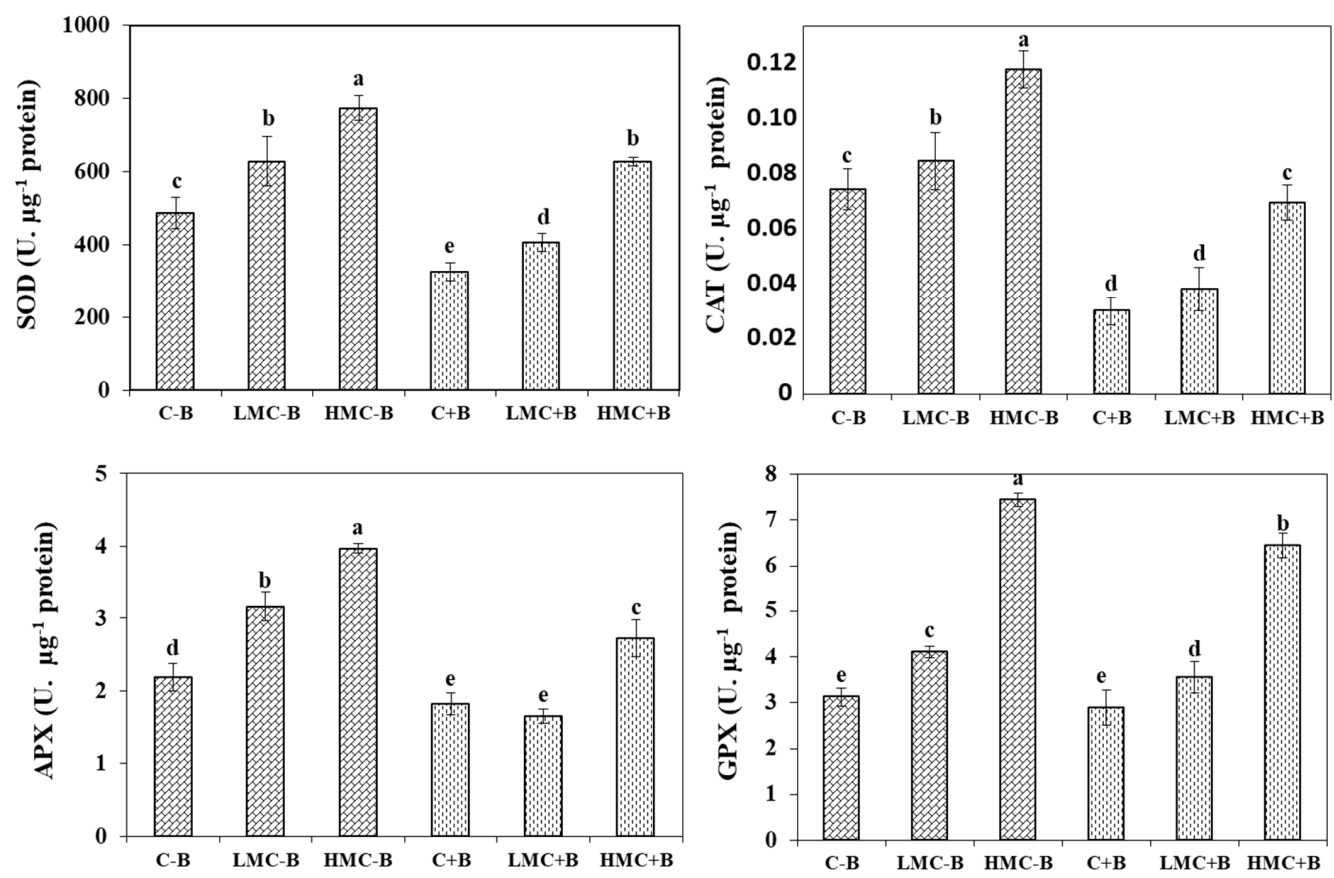

Figure 3. Enzyme activity of superoxide dismutase (SOD), catalase (CAT), ascorbate peroxidase (APX), and guaiacol peroxidase (GPX) in roots plants grown under different treatments. Data are means \pm SE of five determinations. Within the same graph, different letters indicate significant differences at $p<0.05$. C-B: control without inoculation; LMC-B: low metal concentrations, without inoculation; HMC-B: high metal concentrations, without inoculation; $\mathrm{C}+\mathrm{B}$ : control inoculated with bacteria consortium; $\mathrm{LMC}+\mathrm{B}$ : low metals concentrations, inoculated with bacteria consortium; $\mathrm{HMC}+\mathrm{B}$ : high metal concentrations, inoculated with bacteria consortium.

\subsection{Evaluation of the Overall Stress: The Oxidative Stress Index (OSI)}

To estimate the overall oxidative stress, the OSI was proposed [34,45]. The high value of OSI was recorded in non-inoculated plants grown at HMC, for which the OSI was almost twice than the control. The inoculation with the consortium reduced the value of OSI below 1 for both the control (without metal supplementation) and LMC, values that are considered to indicate non-stressed plants, whereas at the highest metal concentration (HMC), the value of OSI was higher than 1 (Figure 4).

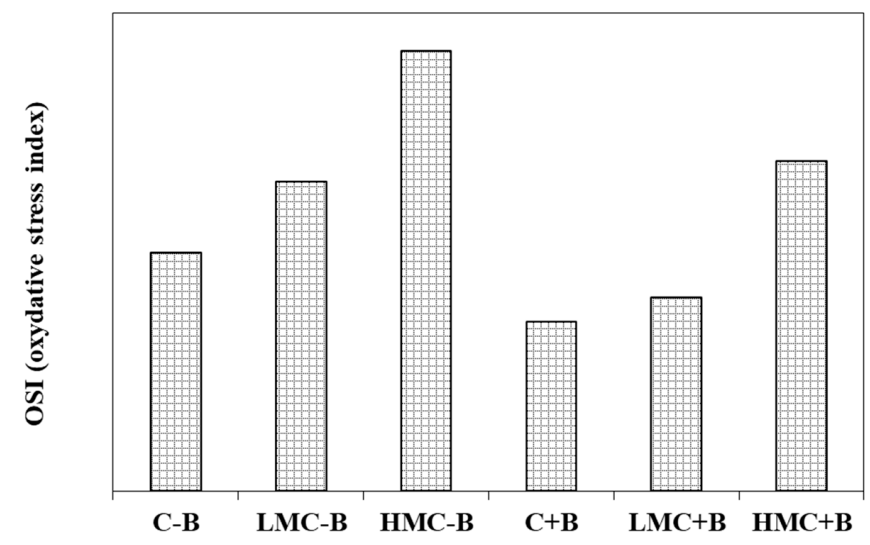

Figure 4. Oxidative stress index (OSI) in roots of plants grown under different treatment. C-B: control without inoculation; LMC-B: low metal concentrations, without inoculation; HMC-B: high metal concentrations, without inoculation; $\mathrm{C}+\mathrm{B}$ : control inoculated with the bacterial consortium; $\mathrm{LMC}+\mathrm{B}$ : low metals concentrations, inoculated with bacteria consortium; $\mathrm{HMC}+\mathrm{B}$ : high metal concentrations, inoculated with the bacterial consortium. 


\subsection{Expression of Stress-Related Genes}

In order to understand the molecular mechanisms underlying plants root protection by bacteria, expression levels of several stress related genes were investigated. Based on their involvement in metal stress management, nine genes were selected which were representative of the different pathways for stress alleviation [34] and their involvement in bacteria-plant symbiosis [39] (Table 1), as follows: Histone 1 (His1) was used as the housekeeping gene; NRAMP1 (natural resistance-associated macrophage protein) is a Mn transporter which is known to be overexpressed under As and Cd stress in rice [48,49]; glutathione reductase (GR) is involved in the maintenance of the redox state [36]; and phytochelatin synthase $(P C S)$ is involved in the synthesis of phytochelatins for metal complexation [50]. The gene CP450 coding for cytochrome P450 is involved in stress management under xenobiotics and metal exposure $[51,52]$. The gene coding for phenylalanine ammonia lyase $(P A L)$ is involved in secondary metabolism and lignin synthesis, which is induced by metals $[34,53,54]$ and the receptor of ethylene (ETR1) the plant hormone more related to stress situations [55].

In the first place, it has to be noted that the quality of RNA obtained from samples of roots in the highest metal concentration HMC and non-inoculated was insufficient and amplification of any gene was observed, even the housekeeping gene, so they were discarded. This could be also interpreted as the highest stress in these plants. The results of relative gene expression are illustrated in Figure 5. Besides His1, four genes gave amplification signals, in particular NRAMP1, GR, PS, and CP450, whereas PAL and ETR1 did not produce any amplification signal or the identity of the PCR product could not be confirmed by sequencing. Since the differences corresponded to less than one PCR cycle, expression levels between 0.5 and 2.0 as compared to the control (plants without metals and without inoculation) were not considered as statistically significant compared with the control (plants with no heavy metal supplementation and no inoculation). In non-inoculated plants, the presence of metals at the lowest concentration LMC led to an enhancement of the expression of GR (20-fold) revealing a strong oxidative burst in these plants. The same concentration of metals did not produce an induction of this activity in inoculated plants, in which overexpression was only measured at the highest metal concentration HMC. Regarding PCS, a 6.5-fold induction was observed in non-inoculated plants, reflecting metal detoxification through complexation and vacuole compartmentalization. However, in inoculated plants, this induction was abolished. The Mn transporter NRAMP1 was repressed by metals in non-inoculated plants, maybe as a mean to block toxic metal uptake. By contrast, an enhancement of 2.2-fold was registered in plants grown at the highest metal concentration HMC upon inoculation. In addition, the gene CP450 was induced, more than by metals, by the inoculation treatment (2.44-fold enhancement) even in the absence of metals. 

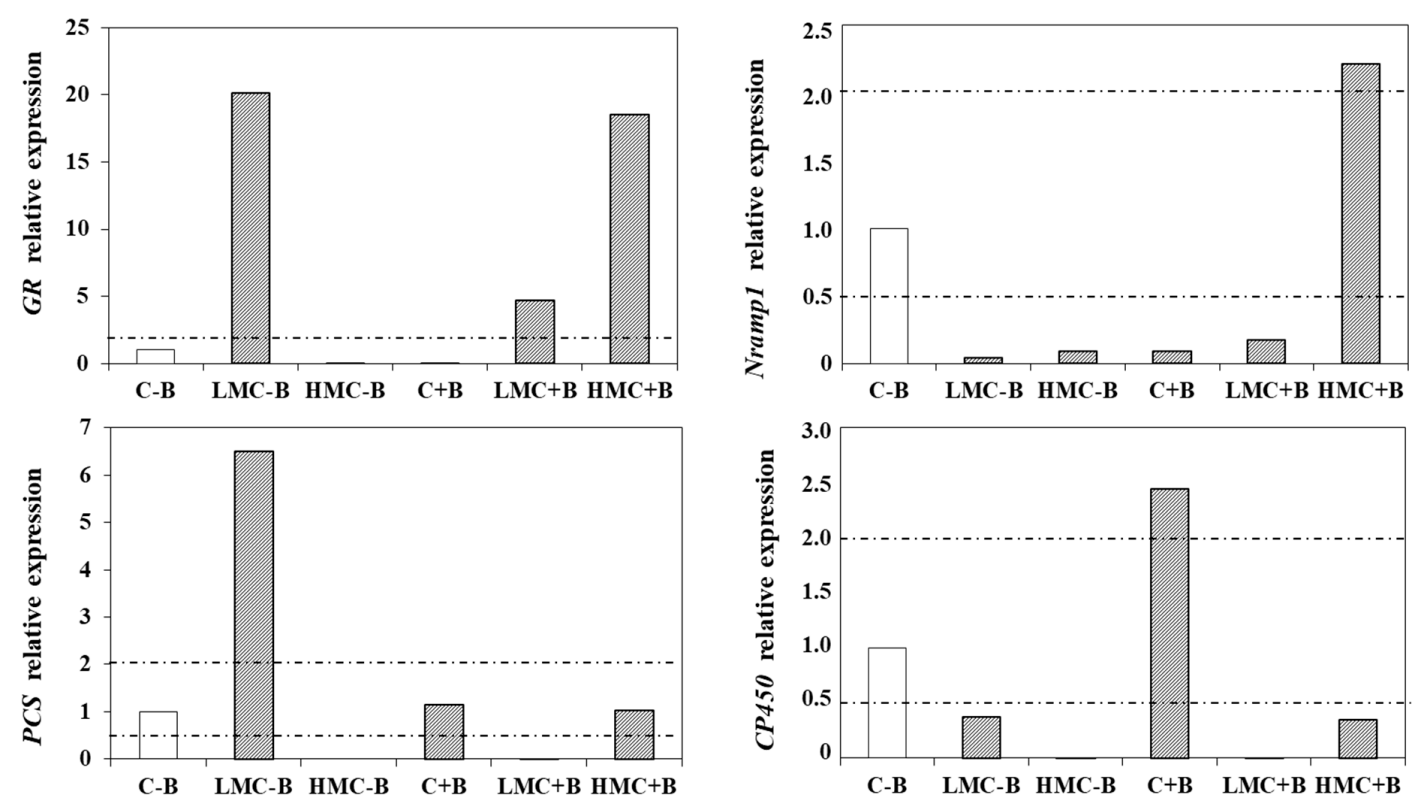

Figure 5. Expression of glutathione reductase $(G R)$, natural resistance-associated macrophage protein transporters (NRAMP1), phytochelatin synthase (PCS), and cytochrome P450 (CP450) in roots of plant grown under different concentrations of metals and/or inoculation treatments. For each gene, the expression level is relative to that of control plants (without metals and non-inoculated) considered as 1. Expression levels were calculated using His1 as the housekeeping gene. Dashed lines indicate expression between 0.5 and 2, considered as not significantly different in qT-PCR, since changes in gene expression would correspond to less than one cycle amplification. C-B: control without inoculation; LMC-B: low metal concentrations, without inoculation; HMC-B: high metal concentrations, without inoculation; $\mathrm{C}+\mathrm{B}$ : control inoculated with the bacterial consortium; $\mathrm{LMC}+\mathrm{B}$ : low metals concentrations, inoculated with the bacterial consortium; $\mathrm{HMC}+\mathrm{B}$ : high metal concentrations, inoculated with the bacterial consortium.

\subsection{Metal Accumulation in Plants}

The accumulation of metal in plants is shown in Figure 6. Alfalfa is a non-hyperaccumulating plant, so metal is mainly accumulated in roots, with low translocation to shoots. As the external concentration of metals increased, so did the accumulation of metals in both shoots and in roots. At the highest metal concentration (HMC), the accumulation of $\mathrm{Cu}$ and $\mathrm{Pb}$ reached the threshold recommended for animal grazing, whereas $\mathrm{Zn}$ accumulation surpassed this limit. In all cases, the inoculation with bacterial consortium led to a diminution of metal accumulation; this decrease was observed both in shoots (reductions between $42 \%$ and $65 \%$ depending on the metal) and in roots (where the reductions were between $47 \%$ and $66 \%$ depending on the metal). Moreover, inoculation with the selected strains allowed the safe cultivation of this plant on metal polluted soils, since all the values of metal accumulation in aboveground tissues always remained below the threshold for animal grazing [56]. 
$\mathrm{Cu}$

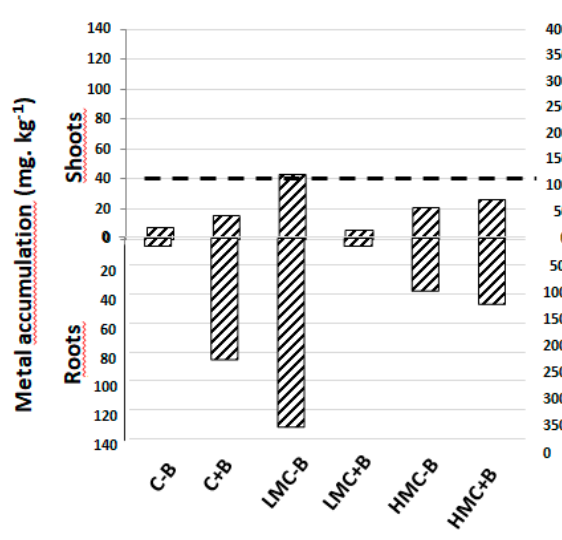

$\mathrm{Pb}$

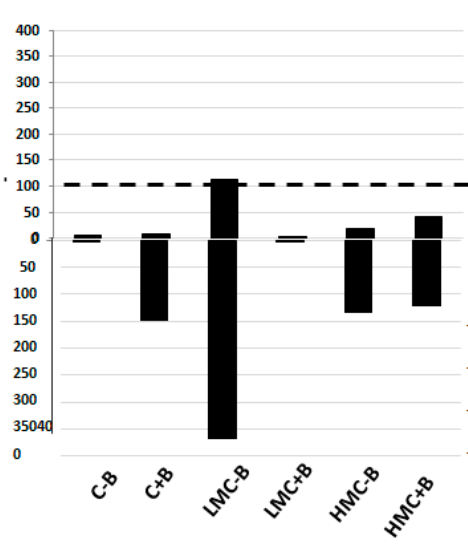

Zn

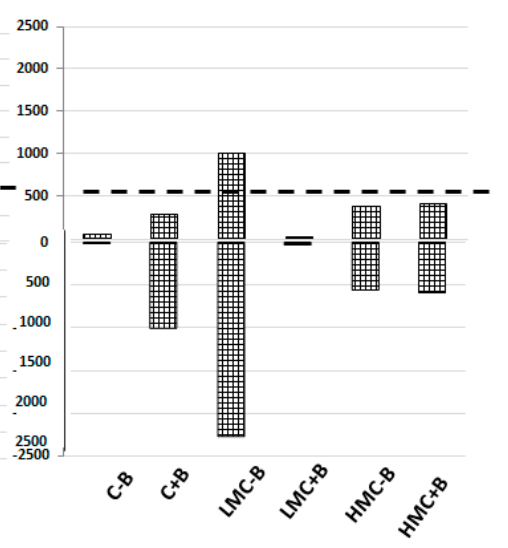

Figure 6. Metal accumulation in shoots and roots of Medicago sativa plants in the presence of different metal concentrations and/or inoculation treatments. C-B: Control without inoculation; LMC-B: low metal concentrations, without inoculation; HMC-B: high metal concentrations, without inoculation; $\mathrm{C}+\mathrm{B}$ : control inoculated with the bacterial consortium; $\mathrm{LMC}+\mathrm{B}$ : low metal concentrations, inoculated with the bacterial consortium; $\mathrm{HMC}+\mathrm{B}$ : high metal concentrations, inoculated with the bacterial consortium. Dashed lines represent the threshold for animal grazing in aboveground tissue [56].

\subsection{Colonization of Plant Roots by Bacterial Cells}

The colonization of plant roots by the bacteria was analyzed by SEM (Figure 7). When bacteria were applied individually, it could be seen that the PGPR strains DSP1 and DSP17 showed wide root colonization with extensive colonies which almost covered the whole root surface (Figure 7A,B). In the case of the Pseudomonas strain, the presence of a dense web of extracellular material was observed (Figure 7B, detail at the right corner). In the case of the rhizobial strains, root colonization was also observed although not so dense cover as for the PGPR strains (Figure 7C,D). It is noteworthy the formation of some kind of peduncles-like structures or thick fibers by the strain Ensifer meliloti RhLO8, together with extracellular thin fibers (Figure 7B, detail at the right corner) which could be involved in the attachment of this strain to the plant surface. The consortium of the four bacteria also showed a dense root cover, in which the distinct bacterial morphologies were observed (Figure 7E). In plants cultivated in the presence of metals and inoculated with the bacterial consortium, a dense carpet of bacteria was also seen, in which the different morphologies could be detected (Figure 7F), indicating that the plant-bacteria interaction was not abolished but even promoted under metal stress. The presence of a dense web of extracellular material in which the bacteria were entrapped was observed, together with "pedunculated" bacteria probably corresponding to RhLO8. 

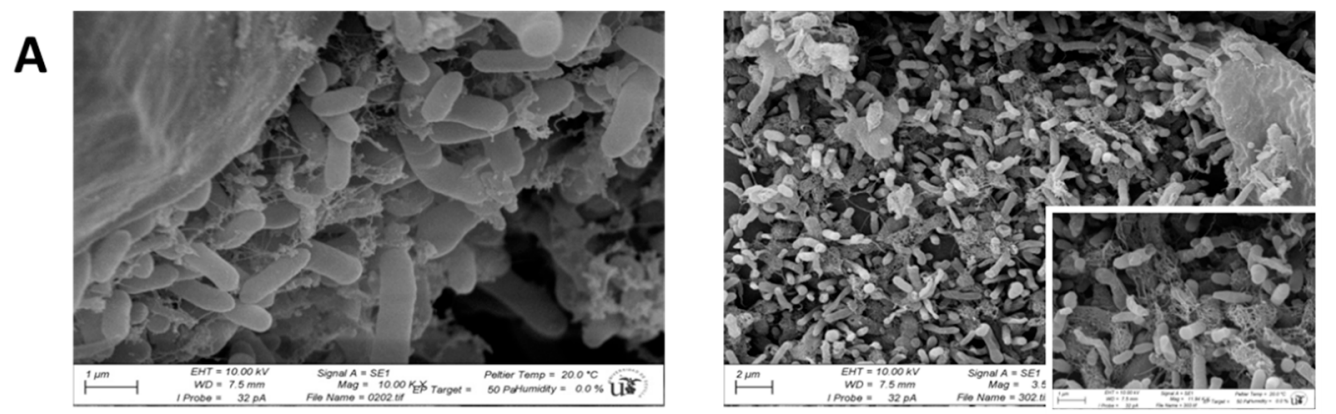

\section{B}
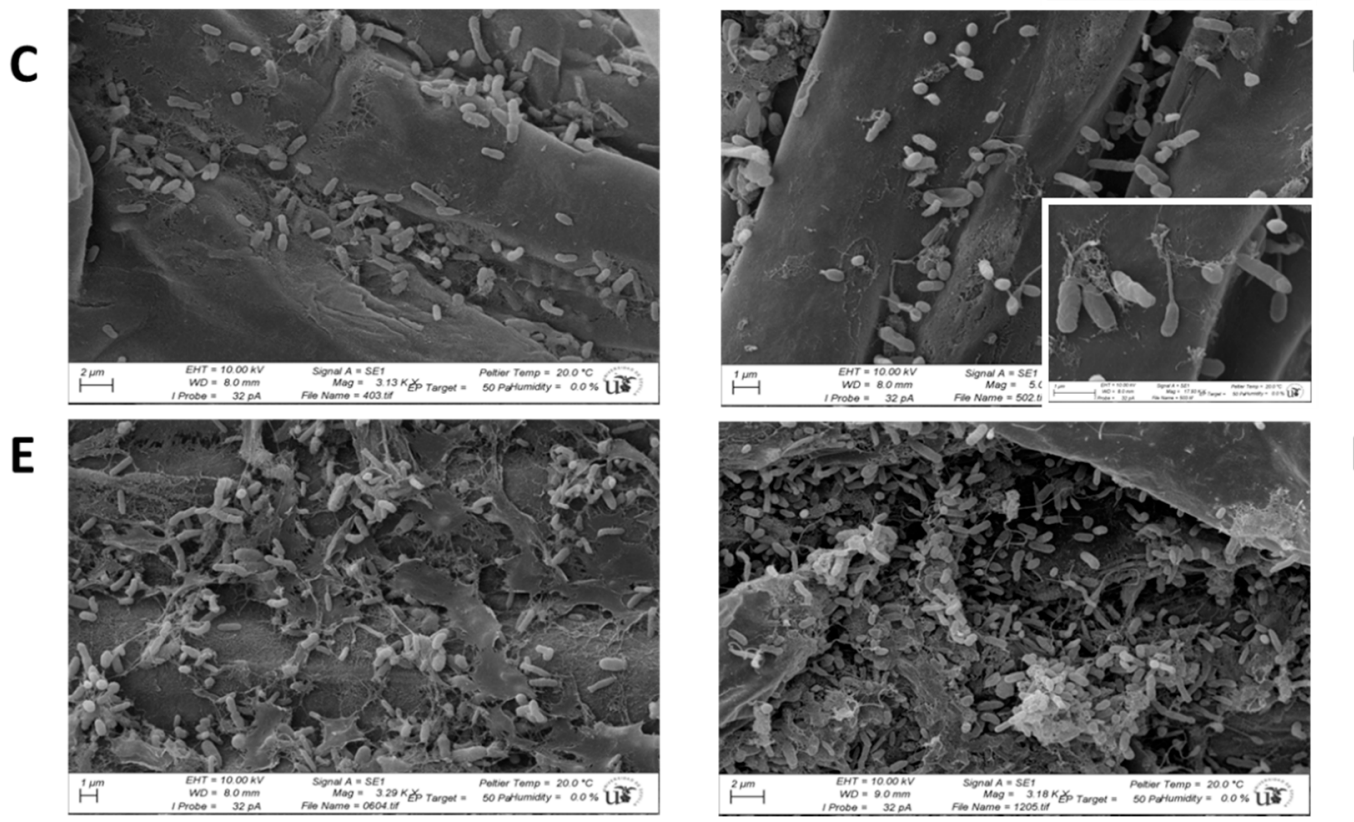

Figure 7. Observation of root colonization by SEM. A. Biofilm formed onto M. sativa roots by Proteus sp. DSP1 (A), Pseudomonas sp. DSP17 (B), Ensifer meliloti RhLO6 (C), and Ensifer meliloti RhLO8 (D) when plants were cultivated in the absence of supplementary metals (note the extracellular polysaccharide fibers produced by the strain DSP17 (Figure 7B, right corner) and the peduncle-like structures formed by the strain RhLO8 (Figure 7B, right corner)). (E) Biofilm formed onto M. sativa roots by the consortium of the four bacteria when plants were cultivated in the absence of supplementary metals (note the different morphologies: thick roods, thin and long rods, and coccobacilli and the fibers of polysaccharide). (F) Biofilm formed onto M. sativa roots by the consortium of the four bacteria in plants grown in the presence of metals (note the different morphologies: thick roods, thin and long rods, and coccobacilli, together with the presence of bacteria showing a peduncle-like structure).

\section{Discussion}

The effect of rhizobacteria inoculation on growth, physiology, heavy metal uptake, ROS scavenging enzymes, and expression of some related of $M$. sativa plants to heavy metal stress was studied. The obtained results showed that $M$. sativa cultivation under heavy metal stress negatively affected the growth parameters (shoot and root length, fresh weight, and leaf number). The toxicity of metals and metalloids to this plant was previously reported; for instance, it inhibits growth and causes a diminution of nodulation by affecting the number of infections [57]. On their side, metals such as $\mathrm{Cd}$, $\mathrm{Cr}, \mathrm{Cu}, \mathrm{Ni}$, and $\mathrm{Zn}$ caused inhibition of seed germination and of the plant growth [58].

In our work, the diminution of growth in the presence of these toxicants correlated with deep changes in the physiological state of the plants, as deduced from the physiological parameters measured, in particular, maximum quantum efficiency of PSII (Fv/ Fm), quantum efficiency of PSII (ФPSII), electron transport rate $(E T R)$, net photosynthetic rate $\left(A_{N}\right)$, stomatal conductance $\left(g_{s}\right)$, and intercellular $\mathrm{CO}_{2}$ concentration $\left(\mathrm{C}_{\mathrm{i}}\right)$. The obtained results probed that heavy metals affected plant physiology and 
reduced the parameters, indicating damage to the photosynthetic machinery. In fact, photosynthesis is one of the processes the most affected by heavy metals such as copper [59] and cadmium [60].

Our results prove that the inoculation of plants with rhizobacteria consortium alleviated the stress caused by heavy metals, enhancing all the growth parameters so that the yield of inoculated plants grown in the presence of metals almost did not show significant differences as compared to unexposed controls. The phytoprotection exerted by bacteria against heavy metal stress correlated with an increment of all physiological parameters recorded with the exception of $C_{i}$. Abundant literature is being produced on the positive effect of inoculation with metallo-resistant bacteria on plants cultivated under metal stress. For instance, cultivation of Atriplex halimus and Arthrocnemum macrostachyum in sediment polluted with heavy metals showed a reduction in chlorophyll florescence and gas exchange, while inoculation with bacteria improve them [27,34,61]. Multiple mechanisms account for this effect, since bacteria can enhance plant nutrition through phosphate solubilization, iron acquisition, nitrogen fixation, etc. Besides, they can stimulate plant growth through secretion of auxins, or they can reduce plant stress via the ACC-deaminase activity. [62-64] There were effects on mineral nutrition; particularly affected were two elements: phosphorus and sodium. In this context, it should be remembered that some of the bacteria displayed phosphate solubilizing ability, perhaps increasing the content of $\mathrm{P}$ in plants, both in shoots and roots. It would be interesting to determine the salt tolerance of the bacteria since, having being isolated from a desert area, it is possible that they could display drought and salt tolerance and could be the explanation for the increase in Na content in inoculated roots $[65,66]$.

In order to counterbalance the production of ROS due to metal exposure, plants synthesize non-enzymatic metabolites (ascorbate, glutathione and polyphenols) and enzymes (CAT, SOD, GPX and APX) under metal stress condition [34,36]. Some studies reported that rhizobacteria inoculation can reduce the stress of plants grown on sediments with different physicochemical properties $[20,22,27,37,65]$. Nonetheless, Arthrocnemum macrostachyum inoculation with bacteria consortium from the endosphere showed less significant effects in comparison with bacteria consortium from the rhizosphere [67]. The mechanisms underlying this protective effect are being deciphered. Cultivation of plants under metal stress increased the levels of ROS-scavenging enzymes SOD, CAT, APX, and GPX, while the inoculation with bacteria decreased these parameters [27,34]. The lower levels of OSI (a parameter introduced to get an overall idea of the oxidative stress) indicated that rhizobacteria can fully mitigated the oxidative stress induced by heavy metals [34].

In a second approach, expression levels of nine genes related to heavy metal stress management and nodulation symbiosis were investigated. Four genes were amplified with our primers and conditions. In our hands, the genes amplified were NRAMP1, GR, PCS, and CP450. The rest of the genes did not give any PCR product upon using DNA as the template or the product was not confirmed by sequencing. Since the primers were designed on consensus sequences based on the sequences of several grasses available in the database [34], it is possible that the same sequences are not very conserved in legumes or maybe the amplification conditions have to be optimized for each particular gene. In our case we used the same conditions as in [34]. Our results suggested that gene expression depends on the concentration of heavy metals and the inoculation treatment. Genome-wide expression analysis suggested variable number of genes differentially expressed in root in response to $\mathrm{As}(\mathrm{V}), \mathrm{Cd}$, $\mathrm{Pb}$, and $\mathrm{Cr}(\mathrm{VI})$ stresses. [68] The induction of the phytochelatins synthesis pathways is evident by the enhanced expression of the gen PCS. Complexation of metals with phytochelatins and storage of the complexes into the vacuole is the main detoxification mechanism is non-hyperaccumulating plants as it is the case of alfalfa $[17,39,50]$. Moreover, glutathione, besides being the substrate for the synthesis of phytochelatins, plays a fundamental role in management of the stress produced by metal exposure and hence the induction of GR in order to keep a pool of reduced glutathione [36,37]. Both genes have differential expression in the presence or the absence of bacteria: whereas GR expression seems to be enhanced by the bacteria, probably reflecting the better management of the stress in inoculated plants, PCS expression was higher in non-inoculated plants, maybe due to the lower level of metals 
accumulated in inoculated plants with regard to the non-inoculated partners. Regarding the gene $M R A M P 1$, the regulation by metals is known $[48,49]$. In our case, the inoculation treatment seems to enhance this gene, particularly at the highest metal concentrations. In contrast, the gene CP540 was specifically enhanced by the presence of bacteria, even in the absence of metals. This could be interpreted as a defense mechanism of the plants towards the bacteria. The activation of genes involved in biotic stress has been reported at the first stages of some symbiotic processes such as nodulation of legumes by rhizobial strains $[39,69,70]$.

One of the most important points in this study is the diminution of metal accumulation in alfalfa plants upon inoculation. This is a metal excluder plant $[17,58]$ which accumulates metals preferably in roots, the inoculation treatment even decreased metal translocation to shoots, since all the values of metal concentrations fell far below the threshold for animal grazing. Similar results have been reported recently. For instance, inoculation of Spartina densiflora with gram-negative bacteria led to lower levels of metal accumulation [71]. In this particular, all the bacteria used in our consortium are gram negative, some of them producing a great amount of exoplysaccharide (EPS) which is the case of the rhizobial strains such as Ensifer meliloti RhLO6 and RhLO8. These EPSs are specific signals in the rhizobium-legume symbiosis interaction [72-74]. It is known that metals, positively charged, can be bound to negative charges in EPS (biosorption) through electrostatic interactions [75,76]. Thus, the formation of a dense biofilm onto the root, as we could observe by SEM, may be a barrier to the entrance of metals into the plant root. All four strains have the ability to form this biofilm, in spite that the PGPR strains Proteus sp. DSP1 and Pseudomonas sp. DSP17 formed a more dense structure as compared to the rhizobial strains. In consortium, the different morphologies could be observed. The formation of a "peduncle-like" structure by the strain Ensifer meliloti RhLO8 is outstanding. In our hands, this kind of structure has been only observed when the bacteria are attached to plant roots and we could not detect this peduncle in previous SEM on glass surfaces (Raklami et al., accompanying paper), so it could be suggested that the structure has a biological function. It is known that some rhizobial strains display pili-like or needle-like structures when infecting legumes, not via root hair curling, but via crack entry or intercellular entry $[77,78]$. These pili are part of a type III secretion system harbored by both symbiotic and pathogenic bacteria $[79,80]$. However, these pili have a much thinner diameter, around 6-8 $\mathrm{nm}$ [77]. In our case the peduncle-like structure can have more between 100-200 nm, as observed by SEM. We do not know whether this structure could be a mechanism of rhizobial strains to infect legumes or another kind of structure aimed to attach the bacteria to the plant surface, since it is not produced upon attachment to glass surfaces. This aspect deserves further investigation. In any case, it could be noted that growing plants on agar medium could magnify the colonization of roots by the bacterial strains, and in this sense, semihydroponic cultures or inert substrates such as perlite or vermiculite could provide a more realistic approach to the colonizing ability of the strains.

In our case, it was demonstrated that the dense bacterial biofilm was not abolished, but even promoted, in the presence of metals. In any case, the bacterial biofilm seems to be a barrier for metal entrance into the plant root, thus protecting plants from metal stress and allowing safe cultivation of this plant in moderately polluted soils, since the concentrations of metals in aboveground tissues are always below the maximum recommended for animal grazing [56].

Supplementary Materials: The following are available online at http://www.mdpi.com/2076-2607/7/7/212/s1.

Author Contributions: Conceptualization, K.O., E.M.-N., I.D.R.-L., S.R.-G. and E.P.; Formal analysis, E.M.-N. and E.P.; Funding acquisition, K.O., I.D.R.-L., A.M. and S.R.-G.; Investigation, A.R., A.-I.T., E.M.-N. and S.N.-T.; Methodology, A.R., A.-I.T., E.M.-N. and S.N.-T.; Project administration, K.O., I.D.R.-L., A.M. and S.R.-G.; Supervision, A.-I.T., S.N.-T., A.M. and E.P.; Writing—original draft, A.R.; Writing—review and editing, K.O. and E.P.

Funding: This work has been financed by the project PPR2/2016/42, CNRST Morocco and Ministerio de Economía y Competitividad (MINECO)-cofunded by FEDER, Project CGL2016-75550-R.

Acknowledgments: The Microscopy Service of the CITIUS (University of Sevilla, Spain) is acknowledged for the analysis of the samples by SEM. 
Conflicts of Interest: The authors declare no conflict of interest.

\section{References}

1. FAO (Food and Agricultural Organization). 2015: International Year of Soil. Available online: http://www.fao.org/ soils-2015/fr/ (accessed on 22 July 2019).

2. Mahar, E.; Wang, P.; Ali, A.; Awasti, M.K.; Lahori, A.H.; Wang, Q.; Li, R.; Zhang, Z. Challenges and opportunities in the phytoremediation of heavy metals contaminated soils: A review. Ecotoxicol. Environ. Saf. 2016, 126, 111-121. [CrossRef] [PubMed]

3. Zheljazkov, V.D.; Craker, L.E.; Xing, B.; Nielsen, N.E.; Wilcox, A. Aromatic plant production on metal contaminated soils. Sci. Total Environ. 2008, 395, 51-62. [CrossRef] [PubMed]

4. Ali, H.; Khan, E.; Sajad, A. Phytoremediation of heavy metals-Concepts and applications. Chemosphere 2013, 91, 869-881. [CrossRef] [PubMed]

5. Bolan, N.; Kunhikrishnan, A.; Thangarajan, R.; Kumpiene, J.; Park, J.; Makino, T.; Kirkham, M.B.; Scheckel, K. Remediation of heavy metal(loid)s contaminated soils-to mobilize or to immobilize? J. Hazard. Mater. 2014, 266, 141-166. [CrossRef] [PubMed]

6. Zheljazkov, V.D.; Craker, L.E.; Xing, B. Effects of $\mathrm{Cd}, \mathrm{Pb}$, and $\mathrm{Cu}$ on growth and essential oil contents in dill, peppermint, and basil. Environ. Exp. Bot. 2006, 58, 9-16. [CrossRef]

7. Zheljazkov, V.D.; Jeliazkova, E.A.; Kovacheva, N.; Dzhurmanski, A. Metal uptake by medicinal plant species grown in soils contaminated by a smelter. Environ. Exp. Bot. 2008, 64, 207-216. [CrossRef]

8. Affholder, M.C.; Prudent, P.; Masotti, V.; Coulomb, B.; Rabier, J.; Nguyen-The, B.; Laffont-Schwob, I. Transfer of metals and metalloids from soil to shoots in wild rosemary (Rosmarinus officinalis L.) growing on a former lead smelter site: Human exposure risk. Sci. Total Environ. 2013, 454-455, 219-229. [CrossRef] [PubMed]

9. Masarovičová, E.; Králová, K.; Kummerová, M. Principles of classification of medicinal plants as hyperaccumulators or excluders. Acta Physiol. Plant. 2010, 32, 823-829. [CrossRef]

10. Arpadjan, S.; Çelik, G.; Taşkesen, S.; Güçer, Ş. Arsenic, cadmium and lead in medicinal herbs and their fractionation. Food Chem. Toxicol. 2008, 46, 2871-2875. [CrossRef]

11. Stancheva, I.; Geneva, M.; Hristozkova, M.; Markovska, Y.; Salamon, I. Antioxidant capacity of sage grown on heavy metal-polluted soil, Russ. J. Plant Physiol. 2010, 57, 799-805. [CrossRef]

12. Pandey, V.C.; Rai, A.; Korstad, J. Aromatic crops in phytoremediation: From contaminated to waste dumpsites. In Phytomanagement of Polluted Sites; Market Opportunities in Sustainable, Phytoremediation; Pandey, V.C., Bauddh, K., Eds.; Elsevier: Amsterdam, The Netherlands, 2019; pp. 255-275. [CrossRef]

13. Pajuelo, E.; Rodríguez-Llorente, I.D.; Lafuente, A.; Caviedes, M.A. Legume-Rhizobium symbioses as a tool for bioremediation of heavy metal polluted soils. In Biomanagement of Metal-Contaminated Soils; Environmental Pollution Volume 20; Khan, M.S., Zaidi, A., Goel, R., Musarrat, J., Eds.; Springer: Dordrecht, The Netherlands, 2011; pp. 95-123. [CrossRef]

14. Tak, H.I.; Ahmad, F.; Babalola, O.O. Advances in the application of plant growth-promoting rhizobacteria in phytoremediation of heavy metals. In Reviews of Environmental Contamination and Toxicology; Whitacre, D.M., Ed.; Springer: New York, NY, USA, 2013; Volume 223, pp. 33-52.

15. Hao, X.; Taghavi, S.; Xie, P.; Orbach, M.J.; Alwathnani, H.A.; Rensing, C.; Wei, G. Phytoremediation of heavy and transition metals aided by legume-rhizobia symbiosis. Int. J. Phytoremediat. 2014, 16, 179-202. [CrossRef]

16. Fagorzi, C.; Checcucci, A.; diCenzo, G.C.; Debiec-Andrzejewska, K.; Dziewit, L.; Pini, F.; Mengoni, A. Harnessing rhizobia to improve heavy-metal phytoremediation by legumes. Genes 2018, 9, 542. [CrossRef]

17. Pajuelo, E.; Carrasco, J.A.; Romero, L.C.; Chamber, M.A.; Gotor, C. Evaluation of the metal phytoextraction potential of crop legumes. Regulation of the expression of O-acetylserine (thiol)lyase under metal stress. Plant Biol. 2007, 9, 672-681. [CrossRef] [PubMed]

18. Safranova, V.I.; Piluzza, G.; Bullitta, S.; Belimov, A.A. Use of legume-microbe symbioses for phytoremediation of heavy metal polluted soils: Advantages and potential problems. In Handbook of Phytoremediation; Golubev, I.A., Ed.; Nova Science Publishers, Inc.: Hauppauge, NY, USA, 2011; pp. 443-469.

19. Zubair, M.; Shakir, M.; Ali, Q.; Rani, N.; Fatima, N.; Farooq, S.; Shafiq, S.; Kanwal, N.; Ali, F.; Nasir, I.A. Rhizobacteria and phytoremediation of heavy metals. Environ. Technol. Rev. 2016, 5, 112-119. [CrossRef]

20. Dimkpa, C.; Weinand, T.; Asch, F. Plant-rhizobacteria interactions alleviate abiotic stress conditions. Plant Cell Environ. 2009, 32, 1682-1694. [CrossRef] [PubMed] 
21. Mishra, J.; Singh, R.; Arora, N.K. Alleviation of heavy metal stress in plants and remediation of soil by rhizosphere microorganisms. Front. Microbiol. 2017, 8, 1706. [CrossRef] [PubMed]

22. Ullah, A.; Heng, S.; Munis, M.F.H.; Fahad, S.; Yang, X. Phytoremediation of heavy metals assisted by plant growth promoting (PGP) bacteria: A review. Environ. Exp. Bot. 2015, 117, 28-40. [CrossRef]

23. Gómez-Sagasti, M.T.; Marino, D. PGPRs and nitrogen-fixing legumes: A perfect team for efficient Cd phytoremediation. Front. Plant Sci. 2015, 6, 81. [CrossRef]

24. Benidire, L.; Pereira, S.I.; Castro, P.M.; Boularbah, A. Assessment of plant growth promoting bacterial populations in the rhizosphere of metallophytes from the Kettara mine, Marrakech. Environ. Sci. Pollut. Res. Int. 2016, 23, 21751-21765. [CrossRef]

25. Pérez-Montaño, F.; Alías-Villegas, C.; Bellogín, R.A.; del Cerro, P.; Espuny, M.R.; Jiménez-Guerrero, I.; López-Baena, F.J.; Ollero, F.J.; Cubo, T. Plant growth promotion in cereal and leguminous agricultural important plants: From microorganism capacities to crop production. Microbiol. Res. 2014, 169, 325-336. [CrossRef]

26. Sánchez-Pardo, B.; Zornoza, P. Mitigation of Cu stress by legume-Rhizobium symbiosis in white lupin and soybean plants. Ecotoxicol. Environ. Saf. 2014, 102, 1-5. [CrossRef] [PubMed]

27. Navarro-Torre, S.; Barcia-Piedras, J.M.; Caviedes, M.A.; Pajuelo, E.; Redondo-Gómez, S.; Rodríguez-Llorente, I.D.; Mateos-Naranjo, E. Bioaugmentation with bacteria selected from the microbiome enhances Arthrocnemum macrostachyum metal accumulation and tolerance. Mar. Pollut. Bull. 2017, 117, 340-347. [CrossRef] [PubMed]

28. Peng, J.F.; Song, Y.H.; Yuan, P.; Cui, X.Y.; Qiu, G.L. The remediation of heavy metals contaminated sediment. J. Hazard. Mater. 2009, 161, 633-640. [CrossRef] [PubMed]

29. Roane, T.M.; Pepper, I.L.; Gentry, T.J. Microorganisms and metal pollutants. In Environmental Microbiology, 3rd ed.; Pepper, I.L., Gerba, C.P., Gentry, T.J., Eds.; Academic Press: Cambridge, MA, USA, 2015.

30. Meier, S.; Borie, F.; Bolan, N.; Cornejo, P. Phytoremediation of Metal-Polluted Soils by Arbuscular Mycorrhizal Fungi. Crit. Rev. Environ. Sci. Technol. 2012, 42, 741-775. [CrossRef]

31. Dalvi, A.A.; Bhalerao, S.A. Response of plants towards heavy metal toxicity: An overview of avoidance, tolerance and uptake mechanism. Ann. Plant Sci. 2013, 2, 362-368.

32. Emamverdian, A.; Ding, Y.; Mokhberdoran, F.; Xie, Y. Heavy metal stress and some mechanisms of plant defense response. Sci. World J. 2015, 2015, 756120. [CrossRef] [PubMed]

33. Gill, S.S.; Tuteja, N. Reactive oxygen species and antioxidant machinery in abiotic stress tolerance in crop plants. Plant Physiol. Biochem. 2010, 48, 909-930. [CrossRef]

34. Paredes-Páliz, K.; Rodríguez-Vázquez, R.; Duarte, B.; Caviedes, M.A.; Mateos-Naranjo, E.; Redondo-Gómez, S.; Caçador, M.I.; Rodríguez-Llorente, I.D.; Pajuelo, E. Investigating the mechanisms underlying phytoprotection by plant growth-promoting rhizobacteria in Spartina densiflora under metal stress. Plant Biol. 2018, 20, 497-506. [CrossRef]

35. Hall, J.J. Cellular mechanisms for heavy metal detoxification and tolerance. J. Exp. Bot. 2002, 53, 1-11. [CrossRef]

36. Hossain, M.A.; Piyatida, P.; da Silva, J.A.T.; Fujita, M. Molecular mechanism of heavy metal toxicity and tolerance in plants: Central role of glutathione in detoxification of reactive oxygen species and methylglyoxal and in heavy metal chelation. J. Bot. 2012, 1-37. [CrossRef]

37. Choudhury, F.K.; Rivero, R.M.; Blumwald, E.; Mittler, R. Reactive oxygen species, abiotic stress and stress combination. Plant J. 2016, 90, 856-867. [CrossRef] [PubMed]

38. Shri, M.; Kumar, S.; Chakrabarty, D.; Trivedi, P.K.; Mallick, S.; Misra, P.; Shukla, D.; Mishra, S.; Srivastava, S.; Tripathi, R.D.; et al. Effect of arsenic on growth, oxidative stress, and antioxidant system in rice seedlings. Ecotoxicol. Environ. Saf. 2009, 72, 1102-1110. [CrossRef] [PubMed]

39. Lafuente, A.; Pérez-Palacios, P.; Doukkali, B.; Molina-Sánchez, M.D.; Jiménez-Zurdo, J.I.; Caviedes, M.A.; Rodríguez-Llorente, I.D.; Pajuelo, E. Unraveling the effect of arsenic on the model Medicago-Ensifer interaction: A transcriptomic meta-analysis. New Phytol. 2015, 205, 255-272. [CrossRef] [PubMed]

40. El Alaoui, A. Potentiel des Bactéries et des Plantes dans la Réhabilitation des Sols Pollués par des Rejets Miniers de Draa Sfar et Kettara. Ph.D. Thesis, Faculty of Sciences Semlalia, Cadi Ayyad Univesity, Marrakech, Morocco, 2018; 182p. (In French).

41. Vincent, J.M. A Manual for the Practical Study of Root Nodule Bacteria. In IBP (International Biological Programme); Handbook No. 15; Blackwell Scientific: Oxford, UK, 1970.

42. Von Caemmerer, S.; Farquhar, G.D. Some relationships between the biochemistry of photosynthesis and the gas exchange of leaves. Planta 1981, 153, 376-387. [CrossRef] [PubMed] 
43. Redondo-Gómez, S.; Mateos-Naranjo, E.; Figueroa-Clemente, M.E.; Davy, A.J. Salt stimulation of growth and photosynthesis in an extreme halophyte, Arthrocnemum macrostachyum. Plant Biol. 2010, 12, 79-87. [CrossRef] [PubMed]

44. Duarte, B.; Goessling, J.W.; Marques, J.C.; Caçador, I. Ecophysiological constraints of Aster tripolium under extreme thermal event impacts: Merging biophysical, biochemical and genetic insights. Plant Physiol. Biochem. 2015, 97, 217-228. [CrossRef] [PubMed]

45. Pérez-Palacios, P.; Agostini, E.; Ibáñez, S.G.; Talano, M.A.; Rodríguez-Llorente, I.G.; Caviedes, M.A.; Pajuelo, E. Removal of copper from aqueous solutions by rhizofiltration using genetically modified hairy roots expressing a bacterial Cu-binding protein. Environ. Technol. 2017, 38, 2877-2888. [CrossRef]

46. Livak, K.J.; Schmittgen, T.D. Analysis of relative gene expression data using real-time quantitative PCR and the $2^{-\Delta \Delta C T}$ method. Methods 2001, 25, 402-408. [CrossRef]

47. Broughton, W.J.; Dilworth, M.J. Control of leghaemoglobin synthesis in snake beans. Biochem. J. 1971, 125, 1075-1080. [CrossRef]

48. Tiwari, M.; Sharma, D.; Dwivedi, S.; Singh, M.; Tripathi, R.D.; Trivedi, P.K. Expression in Arabidopsis and cellular localization reveal involvement of rice NRAMP, OsNRAMP1, in arsenic transport and tolerance. Plant Cell Environ. 2014, 37, 140-152. [CrossRef]

49. Takahashi, R.; Ishimaru, Y.; Senoura, T.; Shimo, H.; Ishikawa, S.; Arao, T.; Nakanishi, H.; Nishizawa, N.K. The OsNRAMP1 iron transporter is involved in Cd accumulation in rice. J. Exp. Bot. 2011, 62, 4843-4850. [CrossRef] [PubMed]

50. Cobbett, C.; Goldsbrough, P. Phytochelatins and metallothioneins: Roles in heavy metal detoxification and homeostasis. Ann. Rev. Plant Biol. 2002, 53, 159-182. [CrossRef] [PubMed]

51. Tripathi, R.D.; Tripathi, P.; Dwivedi, S.; Dubey, S.; Chatterjee, S.; Chakrabarty, D.; Trivedi, P.K. Arsenomics: Omics of arsenic metabolism in plants. Front. Physiol. 2012, 3, 275. [CrossRef] [PubMed]

52. Xu, J.; Wang, X.-Y.; Guo, W.-Z. The cytochrome P450 superfamily: Key players in plant development and defense. J. Integr. Agric. 2015, 14, 1673-1686. [CrossRef]

53. Kováčik, J.; Grúz, J.; Klejdus, B.; Štork, F.; Marchiosi, R.; Ferrarese-Filho, O. Lignification and related parameters in copper-exposed Matricaria chamomilla roots: Role of $\mathrm{H}_{2} \mathrm{O}_{2}$ and $\mathrm{NO}$ in this process. Plant Sci. 2010, 179, 383-389. [CrossRef]

54. Pawlak-Sprada, S.; Stobiecki, M.; Deckert, J. Activation of phenylpropanoid pathway in legume plants exposed to heavy metals. Part II. Profiling of isoflavonoids and their glycoconjugates induced in roots of lupine (Lupinus luteus) seedlings treated with cadmium and lead. Acta Biochim. Pol. 2011, 58, $217-223$. [CrossRef] [PubMed]

55. Steffens, B. The role of ethylene and ROS in salinity, heavy metal, and flooding responses in rice. Front. Plant Sci. 2014, 5, 685. [CrossRef]

56. Mendez, M.O.; Maier, R.M. Phytostabilization of mine tailings in arid and semiarid environments. An emerging remediation technology. Environ. Health Perspect. 2008, 116, 278-283. [CrossRef]

57. Pajuelo, E.; Rodríguez-Llorente, I.D.; Dary, M.; Palomares, A.J. Toxic effects of arsenic on SinorhizobiumMedicago sativa symbiotic interaction. Environ. Pollut. 2008, 154, 203-211. [CrossRef]

58. Peralta, J.R.; Gardea-Torresdey, J.L.; Tiemann, K.J.; Gomez, E.; Arteaga, S.; Rascon, E.; Parsons, J.G. Uptake and effects of five heavy metals on seed germination and plant growth in alfalfa (Medicago sativa L.). Bull. Environ. Contam. Toxicol. 2001, 66, 727-734. [CrossRef]

59. Pádua, M.; Cavaco, A.M.; Aubert, S.; Bligny, R.; Casimiro, A. Effects of copper on the photosynthesis of intact chloroplasts: Interaction with manganese. Physiol. Plant. 2010, 138, 301-311. [CrossRef] [PubMed]

60. Dong, J.; Wu, F.-B.; Zhang, G.-P. Effect of cadmium on growth and photosynthesis of tomato seedlings. J. Zhejiang Univ. Sci. B 2005, 6, 974-980. [CrossRef] [PubMed]

61. Mesnoua, M.; Mateos-Naranjo, E.; Pérez-Romero, J.A.; Barcia-Piedras, J.M.; Lotmani, B.; Redondo-Gómez, S. Combined effect of Cr-toxicity and temperature rise on physiological and biochemical responses of Atriplex halimus L. Plant Physiol. Biochem. 2018, 132, 675-682. [CrossRef] [PubMed]

62. Odoh, C.K.; Eze, C.N.; Apki, U.K.; Unah, V.U. Plant growth promoting rhizobacteria (PGPR): A novel agent for sustainable food production. Am. J. Agric. Biol. Sci. 2019, 14, 35-54. [CrossRef]

63. Glick, B.R. Bacteria with ACC deaminase can promote plant growth and help to feed the world. Microbiol. Res. 2014, 169, 30-39. [CrossRef] [PubMed] 
64. Goswami, D.; Thakker, J.N.; Dhandhukia, P.C. Portraying mechanics of plant growth promoting rhizobacteria (PGPR): A review. Cogent Food Agric. 2016, 2, 1127500. [CrossRef]

65. Yang, J.; Kloepper, J.W.; Ryu, C. Rhizosphere bacteria help plants to tolerate abiotic stress. Trends Plant Sci. 2009, 14, 1-4. [CrossRef] [PubMed]

66. Egamberdieva, D.; Kucharova, Z. Selection for root colonising bacteria stimulating wheat growth in saline soils. Biol. Fertil. Soils 2009, 45, 563-571. [CrossRef]

67. Navarro-Torre, S.; Barcia-Piedras, J.M.; Mateos-Naranjo, E.; Redondo-Gómez, S.; Camacho, M.; Caviedes, M.A.; Pajuelo, E.; Rodríguez-Llorente, I.D. Assessing the role of endophytic bacteria in the halophyte Arthrocnemum macrostachyum salt tolerance. Plant Biol. 2017, 19, 249-256. [CrossRef]

68. Dubey, S.; Shri, M.; Misra, P.; Lakhwani, D.; Bag, S.K.; Asif, M.H.; Trivedi, P.K.; Tripathi, R.D.; Chakrabarty, D. Heavy metals induce oxidative stress and genome-wide modulation in transcriptome of rice root. Funct. Integr. Genom. 2014, 4, 401-417. [CrossRef]

69. Chen, T.; Duan, L.; Zhou, B.; Yu, H.; Zhu, H.; Cao, Y.; Zhang, Z. Interplay of Pathogen-induced defense responses and symbiotic establishment in Medicago truncatula. Front. Microbiol. 2017, 8, 973. [CrossRef] [PubMed]

70. Zipfel, C.; Oldroyd, G.E. Plant signalling in symbiosis and immunity. Nature 2017, 543, 328-336. [CrossRef] [PubMed]

71. Paredes-Páliz, K.I.; Mateos-Naranjo, E.; Doukkali, B.; Caviedes, M.A.; Redondo-Gómez, S.; Rodríguez-Llorente, I.D.; Pajuelo, E. Modulation of Spartina densiflora plant growth and metal accumulation upon selective inoculation treatments: Comparison of gram-negative and gram-positive rhizobacteria. Mar. Pollut. Bull. 2017, 125, 77-85. [CrossRef] [PubMed]

72. Leigh, J.A.; Signer, E.R.; Walker, G.C. Exopolysaccharide-deficient mutants of Rhizobium meliloti that form ineffective nodules. Proc. Natl. Acad. Sci. USA 1985, 82, 6231-6235. [CrossRef] [PubMed]

73. Kawaharada, Y.; Kelly, S.; Nielsen, M.W.; Hjuler, C.T.; Gysel, K.; Muszynski, A.; Carlson, R.W.; Thygesen, M.B.; Sandal, N.; Asmussen, M.H.; et al. Receptor-mediated exopolysaccharide perception controls bacterial infection. Nature 2015, 523, 308-312. [CrossRef] [PubMed]

74. Marczak, M.; Mazur, A.; Koper, P.; Żebracki, K.; Skorupska, A. Synthesis of rhizobial exopolysaccharides and their importance for symbiosis with legume plants. Genes 2017, 8, 360. [CrossRef] [PubMed]

75. Volesky, B. Biosorption and me. Water Res. 2007, 41, 4017-4029. [CrossRef]

76. Ayangbenro, A.S.; Babalola, O.O. A New Strategy for Heavy Metal Polluted Environments: A Review of Microbial Biosorbents. Int. J. Environ. Res. Public Health 2017, 14, E94. [CrossRef]

77. Krishnan, H.B.; Lorio, J.; Kim, W.S.; Jiang, G.; Kim, K.Y.; DeBoer, M.; Pueppke, S.G. Extracellular proteins involved in soybean cultivar-specific nodulation are associated with pilus-like surface appendages and exported by a type III protein secretion system in Sinorhizobium fredii USDA257. Mol. Plant-Microbe Interact. 2003, 16, 617-625. [CrossRef]

78. Deakin, W.J.; Broughton, W.J. Symbiotic use of pathogenic strategies: Rhizobial protein secretion systems. Nat. Rev. Microbiol. 2009, 7, 312-320. [CrossRef]

79. Okazaki, S.; Kaneko, T.; Sato, S.; Saeki, K. Hijacking of leguminous nodulation signaling by the rhizobial type III secretion system. Proc. Natl. Acad. Sci. USA 2013, 110, 17131-17136. [CrossRef] [PubMed]

80. Puhar, A.; Sansonetti, P.J. Type III secretion system. Curr. Biol. 2014, 24, R784-R791. [CrossRef] [PubMed]

(C) 2019 by the authors. Licensee MDPI, Basel, Switzerland. This article is an open access article distributed under the terms and conditions of the Creative Commons Attribution (CC BY) license (http://creativecommons.org/licenses/by/4.0/). 